\title{
Soil chemical properties affect the reaction of forest soil bacteria to drought and rewetting stress
}

\author{
Marcin Chodak • Marcin Gołębiewski • Justyna Morawska-Ploskonka • \\ Katarzyna Kuduk • Maria Niklińska
}

Received: 21 July 2014 / Accepted: 10 November 2014 /Published online: 25 November 2014

(C) The Author(s) 2014. This article is published with open access at Springerlink.com

\begin{abstract}
Reaction of soil bacteria to drought and rewetting stress may depend on soil chemical properties. The objectives of this study were to test the reaction of different bacterial phyla to drought and rewetting stress and to assess the influence of different soil chemical properties on the reaction of soil bacteria to this kind of stress. The soil samples were taken at ten forest sites and measured for $\mathrm{pH}$ and the contents of organic $\mathrm{C}\left(\mathrm{C}_{\text {org }}\right)$ and total $\mathrm{N}\left(\mathrm{N}_{\mathrm{t}}\right), \mathrm{Zn}, \mathrm{Cu}$, and $\mathrm{Pb}$. The samples were kept without water addition at $20-30{ }^{\circ} \mathrm{C}$ for 8 weeks and subsequently rewetted to achieve moisture equal to $50-$ $60 \%$ of their maximum water-holding capacity. Prior to the drought period and $24 \mathrm{~h}$ after the rewetting, the structure of soil bacterial communities was determined using pyrosequencing of 16S rRNA genes. The drought and rewetting stress altered bacterial community structure. Gram-positive bacterial phyla, Actinobacteria and Firmicutes, increased in relative proportion after the stress, whereas the Gram-negative bacteria in most cases decreased. The largest decrease in relative abundance was for Gammaproteobacteria and Bacteroidetes. For several phyla the reaction to drought and rewetting stress depended on the chemical properties of soils.
\end{abstract}

Electronic supplementary material The online version of this article (doi:10.1007/s13213-014-1002-0) contains supplementary material, which is available to authorized users.

M. Chodak ( $\square)$

Department of Management and Protection of Environment, AGH

University of Science and Technology, al. Mickiewicza 30,

30-059 Kraków, Poland

e-mail: chodak@agh.edu.pl

M. Gołęiewski

Department of Biotechnology, Nicolaus Copernicus University,

ul. Gagarina 9, 87-100 Toruń, Poland

J. Morawska-Płoskonka $\cdot$ K. Kuduk $\cdot$ M. Niklińska

Institute of Environmental Sciences, Jagiellonian University,

Gronostajowa 7, 30-387 Kraków, Poland
Soil $\mathrm{pH}$ was the most important soil property influencing the reaction of a number of soil bacterial groups (including all classes of Proteobacteria, Bacteroidetes, Acidobacteria, and others) to drought and rewetting stress. For several bacterial phyla the reaction to the stress depended also on the contents of $\mathrm{N}_{\mathrm{t}}$ and $\mathrm{C}_{\mathrm{org}}$ in soil. The effect of heavy metal pollution was also noticeable, although weaker compared to other chemical soil properties. We conclude that soil chemical properties should be considered when assessing the effect of stressing factors on soil bacterial communities.

Keywords Drought and rewetting stress · Forest soils . Bacterial phyla $\cdot$ Soil chemical properties $\cdot$ Pyrosequencing

\section{Introduction}

Soil bacteria constitute an important part of the soil microbial community and play a vital role in the functioning of forest ecosystems (Bauhus and Khanna 1999; Nannipieri et al. 2003). In forest soils, bacteria occur in largest abundance in the uppermost layers - the organic $(\mathrm{O})$ and the accumulation (A) horizon (Raubuch and Beese 1995; Chodak 2002). Bacteria inhabiting the uppermost soil horizons are exposed to various external stressors, the long periods of drought followed by rapid rewetting being the most common ones (Schimel et al. 2007). Several climate models forecast more frequent and longer periods of drought in multiple forested regions of the world (IPCC 2007). Thus, drought and rewetting stress will likely become a more important perturbation to forest biogeochemical cycling in many regions (Maracchi et al. 2005).

Drought affects soil bacteria through osmotic stress and resource competition. Rewetting after a period of drought also causes stress for soil bacteria as they must rapidly dispose their osmolytes in order to counteract rapid flow of water into their 
cells (Schimel et al. 2007). Long periods of drought may lead to changes in the soil bacterial community structure (Schimel et al. 1999, 2007; Hueso et al. 2012) resulting in altered patterns of $\mathrm{C}$ and $\mathrm{N}$ cycling in the ecosystem. This is because some specific soil microbial processes are carried out by specialized bacteria that may be vulnerable to drought and rewetting stress (Evans and Burke 2012). For instance, Göransson et al. (2013) found lower rates of respiratory response to rewetting in drought-exposed forest soils compared with the soils that did not experience drought periods. Pesaro et al. (2004) reported reduced degradation and mineralization of organic pesticides in dried and rewetted soils compared to the degradation and mineralization in undisturbed control.

Different groups of soil bacteria may have different vulnerability to drought and rewetting stress (Uhlirova et al. 2005; Schimel et al. 2007) depending on their copiotrophic or oligotrophic character (Fierer et al. 2007) or their desiccation-related life-strategies (Barnard et al. 2013). However, studies on the reaction of different bacterial groups to the drought and rewetting stress usually neglected the importance of soil chemical properties for this process. It has been shown that taxonomic structure and diversity of soil bacterial communities are determined by soil properties such as quantity and quality of soil organic matter, moisture conditions or soil acidity (Allison and Martiny 2008; Rousk et al. 2010; Nacke et al. 2011; Kuramae et al. 2012; Preem et al. 2012; Tripahti et al. 2012; Chodak et al. 2013). We hypothesized, therefore, that the reaction of soil bacteria to drought and rewetting stress may depend not only on their intrinsic copiotrophic or oligotrophic characteristics or desiccationrelated life-strategy, but may depend also on soil properties. In particular, the presence of other stressors such as high acidity or large heavy metal concentration could affect the reaction of soil bacteria to drought and rewetting stress.

The objectives of this study were to test the reaction of different bacterial phyla to drought and rewetting stress and to investigate how soil properties influence the reaction of different bacterial phyla to drought and rewetting.

\section{Material and Methods}

Study sites

Soil samples were collected at ten sites in southern Poland. In order to avoid a pseudoreplication problem (Hurlbert 1984), the sampling sites were located in two regions and at large distances from each other. Five sites were located in the Krakowsko-Czestochowska Upland nearby the city of Olkusz and another five in the Silesian Lowland between the cities of Legnica and Głogów. Within each region the five samples represented a heavy metal pollution gradient ranging from clean soils to heavily polluted ones.
The Krakowsko-Częstochowska Upland is made of Upper Jurassic rocks covered by Quaternary sands and loess. The annual precipitation averages $600 \mathrm{~mm}$ to $700 \mathrm{~mm}$ and the mean annual temperature is $8^{\circ} \mathrm{C}$. The Olkusz area is the major zinc and lead industry region of Poland; the country's largest zinc smelter was built there in 1967. In the late 1980s, yearly dustfall in the vicinity of the smelter was ca. 118 tons $\mathrm{km}^{-2}$. Long-term industrial activity brought about severe pollution of forest soils with concentrations of $\mathrm{Zn}$ and $\mathrm{Pb}$ locally exceeding 4,600 mg kg-1 and 1,650 $\mathrm{mg} \mathrm{kg}^{-1}$, respectively (Niklińska et al. 2005).

The Silesian Lowland is a large plain located in southwestern Poland. The sampling area was situated in its northwestern part. The climate of the area is temperate with mean annual temperature of $8.9^{\circ} \mathrm{C}$ and annual precipitation averaging 500 - $550 \mathrm{~mm}$. Since the late 1960s, the region has become a major copper production center in Poland. At present there are four copper ore mines and two copper smelters in the area. The industrial activity caused pollution of forest soils in the area with $\mathrm{Cu}$ and to some extent with $\mathrm{Pb}$. The concentrations of these elements in organic horizons of forest soils reach nearly $1,200 \mathrm{mg} \mathrm{kg}^{-1} \mathrm{Cu}$ and $515 \mathrm{mg} \mathrm{kg}^{-1} \mathrm{~Pb}$ (Niklińska et al. 2006).

\section{Soil sampling}

The samples of organic $(\mathrm{O})$ and A horizons were taken in June 2009 at ten sampling sites (area of each site ca. 1 ha). All the sampling sites were covered by Scots pine (Pinus sylvestris) forest stands (forest type: Vaccinio Myrtilli-Pinetum). The soils at the sampling sites were classified as Podzols developed from sands (clay content $<5 \%$ ). The humus forms ranged from moder to mor (supplementary material Table S1). At each site the samples of $\mathrm{O}$ and A horizon were taken at five locations lying at the corners and in the middle of the sampling site. The samples from the five locations were sieved $(10 \mathrm{~mm}$ and $2 \mathrm{~mm}$ mesh for $\mathrm{O}$ and A horizons, respectively) and transported to the laboratory. In the laboratory the samples were divided into two parts. One part was airdried and used for physical, physico-chemical, and chemical analyses, and the other was stored in the dark, at $4{ }^{\circ} \mathrm{C}$ and used for microbial analyses.

\section{Chemical and physical analyses}

The samples were analyzed for organic $\mathrm{C}\left(\mathrm{C}_{\mathrm{org}}\right)$ and total $\mathrm{N}$ $\left(\mathrm{N}_{\mathrm{t}}\right.$ ) content by dry combustion using a CHNS analyzer (Vario EL III, Elementar Analysensysteme GmbH). The total concentrations of $\mathrm{Zn}, \mathrm{Pb}$, and $\mathrm{Cu}$ in the samples were measured after wet digestion in concentrated $\mathrm{HNO}_{3}$ with a gradual temperature increase from $50^{\circ} \mathrm{C}$ to $150^{\circ} \mathrm{C}$ using flame atomic absorption spectrometry with a graphite furnace technique (Perkin Elmer, AAnalyst 800). The $\mathrm{pH}$ was measured in 
$1 \mathrm{M} \mathrm{KCl}$ at a 1:2.5 ratio (sample:liquid, w:v) using a digital $\mathrm{pH}$-meter (Nester Instr.). The texture of A horizon samples was determined using a hydrometer method (Sheldrick and Wang 1993). Maximum water-holding capacity (WHC) was determined gravimetrically according to Schlichting and Blume (1966).

\section{Drought and rewetting stress experiment}

The soil samples from each site were pooled (on dry weigh basis) to form two mixed samples representative for $\mathrm{O}$ and $\mathrm{A}$ horizons at this site and used in a drought and rewetting stress experiment.

The mixed samples (ca. $100 \mathrm{~g}$ d.w.) were placed in plastic cups without a lid (vol. $125 \mathrm{ml}$ ) and supplemented with deionized water to achieve a moisture level equal to 50 $60 \%$ of their maximum WHC. The moistened samples were stored for a week in the dark at $22{ }^{\circ} \mathrm{C}$ to enable acclimation after sampling and pretreatment (Nielsen and Winding 2002). After this time, the subsamples were taken to measure initial taxonomic structure and diversity of soil bacterial communities. Subsequently, the samples were placed under drought conditions (temperature $20{ }^{\circ} \mathrm{C} / 30{ }^{\circ} \mathrm{C}$ in 12 -h intervals, no water addition) for 8 weeks. After this time, the samples were rewetted to obtain a moisture level equal to $50-60 \%$ of their maximum WHC. The subsamples for measurement of soil bacterial community structure and diversity were taken $24 \mathrm{~h}$ after the rewetting.

\section{Microbial biomass estimation}

Microbial biomass $\left(\mathrm{C}_{\text {mic }}\right)$ was assessed with substrate-induced respiration (SIR) method (Anderson and Domsch 1978). Briefly, the fresh soil samples ( $5 \mathrm{~g}$ d.w. for $\mathrm{O}$ horizon and $50 \mathrm{~g} \mathrm{~d}$.w. for A horizon) were adjusted to $50 \pm 5 \%$ of their maximum water-holding capacity, amended with $0.02 \mathrm{~g}$ glucose monohydrate $\mathrm{g}^{-1}$ soil and incubated at $22^{\circ} \mathrm{C}$ in gas-tight jars for $4 \mathrm{~h}$ for $\mathrm{C}_{\text {mic }}$. The jars contained small vessels with $5 \mathrm{ml}$ $0.2 \mathrm{M} \mathrm{NaOH}$ to trap the evolved $\mathrm{CO}_{2}$. After opening the jars, $2 \mathrm{ml} \mathrm{BaCl}_{2}$ was added to the $\mathrm{NaOH}$, and the excess hydroxide was titrated with $0.1 \mathrm{M} \mathrm{HCl}$ in the presence of phenolphthalein as indicator. $\mathrm{C}_{\text {mic }}$ was calculated from the SIR rate according to the equation: $\mathrm{C}_{\text {mic }}\left(\mathrm{mg} \mathrm{g}^{-1}\right)=40.04 \mathrm{y}+0.37$, where $\mathrm{y}$ is given in $\mathrm{ml} \mathrm{CO}_{2} \mathrm{~h}^{-1} \mathrm{~g}^{-1}$.

Extraction of DNA from soils, PCR amplification, and pyrosequencing

The DNA was extracted from approximately $0.3 \mathrm{~g}$ of soil using a modified protocol of Yeates et al. (1997) based on bead beating cell lysis and SDS treatment, followed by polyethylene glycol (PEG)/sodium chloride and phenol:chloroform:isoamyl alcohol $(25: 24: 1, \mathrm{v} / \mathrm{v} / \mathrm{v})$ nucleic acid extraction. The DNA extracted was quantified and checked for quality using a NanoDrop 1000 spectrophotometer (Nanodrop Technologies, Wilmington, DE, USA) and amplified using a polymerase chain reaction (PCR). In each PCR reaction $100 \mathrm{ng}$ of the extracted DNA was used. For the PCR amplification of $16 \mathrm{~S}$ rRNA genes of soil bacteria we used the forward amplicon fusion primer composed of the GS FLX Titanium B Primer sequence and the $27 \mathrm{~F}$ primer sequence (Liu et al. 2007), and the reverse amplicon fusion primer composed of the GS FLX Titanium amplicon A Primer, 8-bp-long Multiplex Identifier sequence (Hamady et al. 2008) and the 338R primer sequence (Liu et al. 2007). The PCR amplification was carried out in the Mastercycler (Eppendorf) in 20- $\mu$ l reaction mixtures containing: $2 \mathrm{U}$ of Taq Polymerase (Fermentas), $2 \mu \mathrm{l}$ of $10 \times$ PCR buffer with $\left(\mathrm{NH}_{4}\right)_{2} \mathrm{SO}_{4}$ (Fermentas), $1.5 \mu \mathrm{M}$ of each forward and reverse primer, $1.5 \mathrm{mM}$ of $\mathrm{MgCl}_{2}, 0.2 \mathrm{mM}$ of each $\mathrm{dNTP}$, $1.6 \mu \mathrm{l}$ of bovine serum albumin (Fermentas), $10.1 \mu \mathrm{l}$ of $\mathrm{H}_{2} \mathrm{O}$, and $1 \mu \mathrm{l}$ of diluted DNA. The PCR cycling scheme was the following: $95{ }^{\circ} \mathrm{C}$ for $3.5 \mathrm{~min}$, followed by 34 cycles at $94{ }^{\circ} \mathrm{C}$ $(30 \mathrm{~s}), 55^{\circ} \mathrm{C}(1 \mathrm{~min}), 72^{\circ} \mathrm{C}(1.5 \mathrm{~min})$, and a final extension step at $72{ }^{\circ} \mathrm{C}$ for $10 \mathrm{~min}$. Each sample was amplified in a separate reaction mixture containing a uniquely barcoded right primer, containing the MID sequence used in the next steps of analysis to assign sequences to particular samples. The DNA amplicons were mixed into approximately equimolar quantities based on the estimation of PCR product concentration trough agarose gel electrophoresis and purified using the MinElute PCR Purification Kit (QIAGEN). Purified pools were then sequenced as part of a single 454 FLX run according to the 454 Amplicon Sequencing protocols provided by the manufacturer (Roche 454) at the Institute of Biochemistry and Biophysics, Polish Academy of Sciences in Warsaw.

Bioinformatic analyses, phylogenetic assignment, and clustering of $16 \mathrm{~S}$ rRNA gene fragments

Raw reads were extracted from the .sff files with sff_extract with adapters clipping $(-\mathrm{c})$ Blanca and Chevreux (2010). The downstream analyses were performed with the MOTHUR package v. 1.20.3 (Schloss et al. 2009). First, the reads were quality trimmed and reverse complemented, then the high quality set was dereplicated and aligned to the SILVA reference alignment. The aligned sequences were screened for those that did not cover the desired region of the alignment (start before column 2000, end on column 6326), and then the gap-only columns and columns containing at least one terminal gap symbol were filtered out of the alignment. The chimeras were identified using the Uchime algorithm (Edgar et al. 2011) implemented in MOTHUR. The sequences more numerous than the one being checked were used as possible chimera parents (Quince et al. 2001). PCR and residual sequencing noise were removed by Single Linkage Preclustering as described in Huse et al. (2007). 
For average neighbor clustering-based operational taxonomic units (OTU), construction of a distance matrix was calculated on the basis of the final alignment with the dist.seqs command of MOTHUR, and OTUs were constructed with the cluster command of MOTHUR.

For community composition assessment, the high quality, non-chimeric reads were classified with classify.seqs, using the SILVA taxonomy file from the MOTHUR website. The assignment method was Bayesian.

The diversity of the bacterial communities was assessed using the Chaol index calculated for OTUs with evolutionary distance of 0.03 (or $97 \% 16 \mathrm{~S}$ rRNA gene sequence similarity).

\section{Statistical analyses}

Heavy metal pollution was expressed as toxicity index (TI) according to the following equation: $\mathrm{TI}=\mathrm{Zn}_{\mathrm{i}} / \mathrm{EC}_{\mathrm{Zn}}+\mathrm{Cu}_{\mathrm{i}} /$ $\mathrm{EC}_{\mathrm{Cu}}+\mathrm{Pb}_{i} / \mathrm{EC}_{\mathrm{Pb}}$ where $\mathrm{Zn}_{i}, \mathrm{Cu}_{i}$ and $\mathrm{Pb}_{i}$ are the concentrations of $\mathrm{Zn}, \mathrm{Cu}$, and $\mathrm{Pb}$ at the $i$-th site and $\mathrm{EC}_{\mathrm{Zn}}, \mathrm{EC}_{\mathrm{Cu}}$, and $\mathrm{EC}_{\mathrm{Pb}}$ are the concentrations of $\mathrm{Zn}, \mathrm{Cu}$, and $\mathrm{Pb}$ causing $50 \%$ reduction in dehydrogenase activity (Welp 1999).

The $\mathrm{C}_{\text {mic }}$, Chao1 index and relative abundances of most abundant bacterial phyla prior to and after the drought and rewetting stress averaged over ten sampling sites were compared using paired sample t-test.

Canonical correspondence analysis (CCA) was used to evaluate the influence of drought and rewetting stress on the structure of soil bacterial communities and to assess the effects of soil properties on the reaction of particular bacterial phyla to this kind of stress. In this analysis, we used the $\mathrm{C}_{\text {org }}$ and $\mathrm{N}_{\mathrm{t}}$ contents as variables representing nutrient availability for the microbes, $\mathrm{pH}$ as a variable representing soil acidity, and TI as variable representing soil pollution with metals. The drought and rewetting stress was included as a dummy variable with 0 representing the microbial communities prior to the stress and 1 representing the communities after the stress.

The statistical analyses were performed with Statgraphics Centurion XVI software (StatPoint, Herndon, VA, USA) and the PAST program Hammer $\varnothing$ et al. (2001).

\section{Results}

Chemical properties of the studied soils

The studied soils were polluted with different loads of $\mathrm{Cu}, \mathrm{Zn}$, and $\mathrm{Pb}$. In the $\mathrm{O}$ horizon, the highest contents of these metals were $1,353 \mathrm{mg} \mathrm{kg}^{-1}, 4,792 \mathrm{mg} \mathrm{kg}^{-1}$, and $1,877 \mathrm{mg} \mathrm{kg}^{-1}$, respectively and the lowest $2 \mathrm{mg} \mathrm{kg}^{-1}, 54 \mathrm{mg} \mathrm{kg}^{-1}$, and $177 \mathrm{mg} \mathrm{kg}^{-1}$, respectively (Table 1). In the A horizon heavy metal contents were approximately ten times lower and reached maximum values of $98.4 \mathrm{mg} \mathrm{kg}^{-1}, 422.4 \mathrm{mg} \mathrm{kg}^{-1}$, and $180.8 \mathrm{mg} \mathrm{kg}^{-1}$. Copper was the main pollutant in the soils of the Legnica region whereas the soils of the Olkusz region were polluted mainly with $\mathrm{Zn}$ and $\mathrm{Pb}$. The calculated $\mathrm{TI}$ values in the $\mathrm{O}$ horizon ranged from 2.1 to 46.1 and in the $\mathrm{A}$ horizon from 0.2 to 4.1 . The studied soils were strongly acidic $(\mathrm{pH}=3.4-5.7)$ (Table 1). The contents of $\mathrm{C}_{\text {org }}$ and $\mathrm{N}_{\mathrm{t}}$ were much higher in the $\mathrm{O}$ horizon than in the $\mathrm{A}$ horizon but the $\mathrm{C}_{\text {org }}$-to- $\mathrm{N}_{\mathrm{t}}$ ratios were similar in both horizons and varied from 19.6 to 45.4 .

The structure and diversity of soil bacterial communities prior to and after the drought and rewetting stress

The $\mathrm{C}_{\text {mic }}$ values prior to stress varied from $0.64 \mathrm{mg} \mathrm{g}^{-1}$ to $2.85 \mathrm{mg} \mathrm{g}^{-1}$ in the $\mathrm{O}$ horizon, and from $0.11 \mathrm{mg} \mathrm{g}^{-1}$ to $0.24 \mathrm{mg} \mathrm{g}^{-1}$ in the A horizon (Table 2). After the stress, $\mathrm{C}_{\text {mic }}$ decreased significantly in both horizons $(\mathrm{p}<0.05)$ and varied from $0.61 \mathrm{mg} \mathrm{g}^{-1}$ to $2.75 \mathrm{mg} \mathrm{g}^{-1}$ and from $0.08 \mathrm{mg} \mathrm{g}^{-1}$ to $0.22 \mathrm{mg} \mathrm{g}^{-1}$ in the $\mathrm{O}$ and A horizons, respectively (Table 2).

Prior to the stress, the values of Chaol index varied between 607 and 3,110 and were much higher in the soils from the Olkusz region than in the soils from the Legnica region. After the stress, the Chaol index values declined, although only in the $\mathrm{O}$ horizon was the decrease statistically significant (Table 2).

In both horizons prior to the stress, the dominating bacterial phylum was Proteobacteria, which constituted up to $57.5 \%$ of the total OTUs detected. Among Proteobacteria the most abundant was the Alphaproteobacteria class, followed by Gammaproteobacteria and Betaproteobacteria (Fig. 1, supplementary material Table S2 and S3). Large shares were found also for Acidobacteria (up to $34.6 \%$ of the total OTUs detected), Actinobacteria (up to $15.2 \%$ of the total OTUs detected), Bacteroidetes (up to $7.0 \%$ of the total OTUs detected) and Planctomycetes (up to $4.2 \%$ of the total OTU's detected). The other bacterial phyla were less abundant (Fig. 1, Tables S2 and S3).

The drought and rewetting stress changed the structures of soil bacterial communities in both soil horizons as indicated by altered average abundances of some bacterial groups (Fig. 1) and by distinct shifts of site points along the stress vectors in the CCA biplots (Fig. 2).

After the drought and rewetting stress, the average share of Proteobacteria phylum decreased significantly in both soil horizons (Fig. 1). Different classes of Proteobacteria were affected differently by the drought and rewetting stress with Gammaproteobacteria showing the largest decrease in both soil horizons studied (Figs. 1 and 2). In the O horizon, the share of Gammaproteobacteria decreased from $15.9 \%$ to $10.0 \%$. In the A horizon, the decrease was even larger (from $13.9 \%$ to $6.5 \%$ ) (Fig. 1). 
Table 1 Chemical properties of soils

\begin{tabular}{llllllllll}
\hline Horizon & Site & $\begin{array}{l}\mathrm{Cu} \\
\mathrm{mg} \mathrm{kg}\end{array}$ & $\mathrm{Zn}$ & $\mathrm{Pb}$ & $\begin{array}{l}\text { Toxicity } \\
\text { index }\end{array}$ & $\mathrm{pH}$ & $\begin{array}{l}\mathrm{N}_{\mathrm{t}} \\
\mathrm{mg} \mathrm{g}^{-1}\end{array}$ & $\mathrm{C}_{\text {org }}$ & $\mathrm{C}_{\text {org-to- }}$ t \\
\hline O & OLK1 & 52 & 4,792 & 1,877 & 46.1 & 5.6 & 6.48 & 160.3 & 24.7 \\
& OLK2 & 28 & 1,946 & 1,319 & 19.7 & 5.0 & 10.87 & 246.0 & 22.6 \\
& OLK3 & 10 & 818 & 747 & 8.6 & 4.7 & 7.11 & 185.3 & 26.1 \\
& OLK4 & 2 & 294 & 404 & 3.2 & 4.4 & 12.96 & 337.6 & 26.0 \\
& OLK5 & 3 & 193 & 198 & 2.1 & 4.8 & 8.14 & 214.2 & 26.3 \\
& LEG1 & 1,353 & 116 & 778 & 40.9 & 3.8 & 14.15 & 393.8 & 27.8 \\
AEG2 & 999 & 77 & 506 & 30.0 & 4.1 & 9.94 & 264.2 & 26.6 \\
& LEG3 & 410 & 54 & 241 & 12.5 & 3.8 & 12.56 & 361.4 & 28.8 \\
& LEG4 & 217 & 74 & 177 & 7.1 & 3.8 & 11.66 & 392.5 & 33.7 \\
& LEG5 & 85 & 56 & 191 & 3.2 & 3.4 & 11.90 & 428.1 & 36.0 \\
& OLK1 & 6.2 & 422.4 & 155.3 & 4.1 & 5.7 & 0.42 & 16.73 & 40.1 \\
& OLK2 & 1.2 & 100.0 & 180.8 & 1.2 & 5.2 & 0.40 & 17.11 & 43.0 \\
& OLK3 & 1.3 & 86.7 & 78.7 & 0.9 & 5.2 & 0.44 & 16.05 & 36.3 \\
OLK4 & 0.5 & 29.6 & 108.7 & 0.4 & 4.6 & 1.66 & 53.31 & 32.2 \\
OLK5 & 0.0 & 45.6 & 66.9 & 0.5 & 5.0 & 0.67 & 24.83 & 37.1 \\
LEG1 & 98.4 & 22.2 & 51.1 & 3.1 & 3.9 & 0.43 & 12.53 & 28.9 \\
LEG2 & 33.5 & 15.1 & 18.6 & 1.1 & 4.6 & 1.84 & 36.06 & 19.6 \\
LEG3 & 12.5 & 11.7 & 21.6 & 0.5 & 4.3 & 0.73 & 19.69 & 27.1 \\
LEG4 & 29.7 & 13.6 & 44.7 & 1.0 & 4.1 & 1.43 & 35.87 & 25.1 \\
LEG5 & 2.5 & 10.4 & 26.7 & 0.2 & 4.2 & 0.60 & 27.21 & 45.4 \\
\hline
\end{tabular}

Negative effect of the drought and rewetting stress was observed also for Bacteroidetes and bacteria classified as others, representing less abundant taxons (Fig. 2). The shares of Chloroflexi, Gemmatimonadetes and Verrucomicrobia were negatively affected by drought and rewetting stress, although abundances of these bacterial phyla depended mainly on soil $\mathrm{pH}$ (Fig. 2).

In both studied soil horizons after the drought and rewetting stress distinctly increased the shares of Firmicutes and Actinobacteria (Figs. 1 and 2). Positive effect of the drought and rewetting stress on the relative abundance was observed also for Acidobacteria in the $\mathrm{O}$ horizon and for Planctomycetes in the mineral soil (Fig. 2).

Relationships between soil chemical properties and the reaction of bacterial phyla to drought and rewetting stress

The first two CCA axes calculated for the $\mathrm{O}$ horizon explained $63.1 \%(\mathrm{p}=0.001)$ and $19.6 \%(\mathrm{p}=0.02)$ of the variance, respectively. For the A horizon, the first CCA axis explained $53.7 \%(\mathrm{p}=0.04)$ and the second axis $37.3 \%(\mathrm{p}=0.01)$ of the variance. In the $\mathrm{O}$ horizon the first $\mathrm{CCA}$ axis was strongly related to $\mathrm{pH}(0.91), \mathrm{C}_{\text {org }}(-0.77)$, and $\mathrm{N}_{\mathrm{t}}(-0.71)$. However, there was also a distinct relationship with the drought and rewetting stress $(-0.31)$. The drought and rewetting stress was strongly related (0.71) to the second CCA axis. However, pronounced relationships were also between the CCA axis 2 and soil $\mathrm{pH}(0.35), \mathrm{C}_{\text {org }}(-0.23)$ content, $\mathrm{N}_{\mathrm{t}}(-0.16)$ content, and TI (0.13). In the mineral soil, the drought and rewetting stress was strongly related to the second CCA axis (0.73). Among the soil properties, only $\mathrm{pH}$ was distinctly related to this axis (0.36), whereas the relationships of contents of $\mathrm{C}_{\text {org }}$ $(-0.05), \mathrm{N}_{\mathrm{t}}(-0.11)$, and TI $(0.04)$ were weak.

\section{Discussion}

The structure of soil bacterial community prior to the drought and rewetting stress

Bacterial communities in both horizons of the studied forest soils were dominated by Proteobacteria followed by Acidobacteria and Actinobacteria. In several studies, by applying different molecular methods, Proteobacteria, Acidobacteria, and Actinobacteria were reported to be the most abundant bacterial phyla (Janssen 2006). In our soils, among Proteobacteria the class Alphaproteobacteria was the most abundant one. A high proportion of Alphaproteobacteria was reported for various deciduous and coniferous forests (Nacke et al. 2011; Kuramae et al. 2012) and seems to be characteristic for forest soil bacterial communities.

The second most abundant phylum in our soils was Acidobacteria. A high proportion of Acidobacteria was found in boreal forest soils (Dimitriu and Grayston 2010), acid soils 
Table 2 Microbial biomass $\left(\mathrm{C}_{\text {mic }}\right)$ and Chaol diversity index in the $\mathrm{O}$ and $\mathrm{A}$ horizons at different sites prior to and after the drought and rewetting stress. Asterisks denote significant difference between the values prior to and after the stress within the horizon ( $\mathrm{p}<0.05$, pairwise t-test)

\begin{tabular}{|c|c|c|c|c|}
\hline \multicolumn{3}{|c|}{$\begin{array}{l}\text { Prior to drought and } \\
\text { rewetting stress (T1) }\end{array}$} & \multicolumn{2}{|c|}{$\begin{array}{l}\text { After drought and } \\
\text { rewetting stress (T2) }\end{array}$} \\
\hline \multicolumn{5}{|c|}{ O Horizon } \\
\hline Site & $\mathrm{C}_{\mathrm{mic}}\left(\mathrm{mg} \mathrm{g}^{-1}\right)$ & Chaol & $\mathrm{C}_{\text {mic }}\left(\mathrm{mg} \mathrm{g}^{-1}\right)$ & Chaol \\
\hline OLK1 & 0.64 & 2,679 & 0.61 & 2,266 \\
\hline OLK2 & 1.29 & 3,110 & 1.17 & 1,682 \\
\hline OLK3 & 1.06 & 1,953 & 0.97 & 1,032 \\
\hline OLK4 & 2.85 & 2,249 & 2.75 & 2,097 \\
\hline OLK5 & 1.33 & 2,499 & 1.26 & 2,670 \\
\hline LEG1 & 1.75 & 795 & 1.59 & 639 \\
\hline LEG2 & 1.09 & 628 & 0.94 & 411 \\
\hline LEG3 & 1.29 & 607 & 1.15 & 473 \\
\hline LEG4 & 1.91 & 860 & 1.65 & 563 \\
\hline LEG5 & 1.38 & 912 & 1.29 & n.d. \\
\hline Mean & $1.46^{*}$ & $1,629^{*}$ & $1.34^{*}$ & $1,315^{*}$ \\
\hline \multicolumn{5}{|c|}{ A Horizon } \\
\hline OLK1 & 0.23 & 2,337 & 0.20 & 2,261 \\
\hline OLK2 & 0.22 & 2,974 & 0.18 & 1,061 \\
\hline OLK3 & 0.18 & 2,174 & 0.17 & 1,739 \\
\hline OLK4 & 0.21 & 1,438 & 0.18 & 1,827 \\
\hline OLK5 & 0.21 & 3,104 & 0.21 & 2,112 \\
\hline LEG1 & 0.24 & 778 & 0.22 & 589 \\
\hline LEG2 & 0.11 & 633 & 0.08 & 705 \\
\hline LEG3 & 0.14 & 581 & 0.13 & 575 \\
\hline LEG4 & 0.22 & 1,177 & 0.21 & 790 \\
\hline LEG5 & 0.13 & 648 & 0.13 & 473 \\
\hline Mean & $0.19^{*}$ & 1,584 & $0.17^{*}$ & 1,213 \\
\hline
\end{tabular}

n.d. - not determined

of temperate forests, as well as in grassland and pasture soils (Nacke et al. 2011). A large abundance of Acidobacteria in different soils indicates their importance for functioning of soils. However, little is known about physiology and metabolic functions of Acidobacteria. Fierer et al. (2007) described Acidobacteria as oligotrophs, favored in poor soils with lower carbon availability. The soils used in our study were acid, sandy textured, with low contents of nutrients and poor water holding capacity. Low fertility of our soils explains therefore the high share of Acidobacteria.

The other phyla such as Bacteroidetes, Firmicutes, Planctomycetes, or others were less abundant in our soils. The studied soils differed in terms of soil bacterial community structure and the main drivers of the observed differences have been described elsewhere (Chodak et al. 2013).

The general composition of bacterial communities did not differ much between the $\mathrm{O}$ and $\mathrm{A}$ horizons. There were only few interlayer differences in the shares of some taxa. The $\mathrm{O}$ horizons

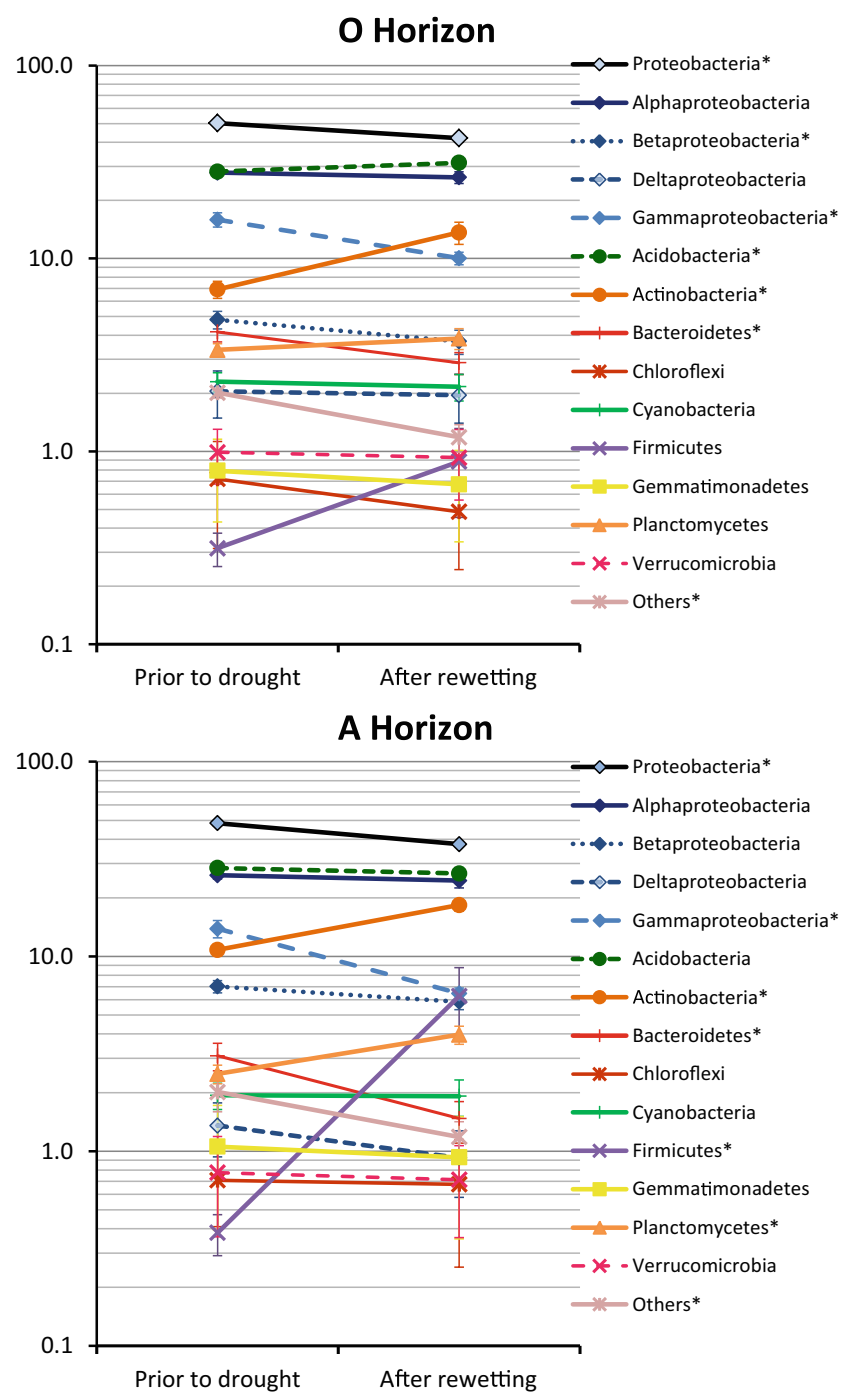

Fig. 1 The relative abundances of most abundant bacterial phyla in the $\mathrm{O}$ and A horizons prior to and after the drought and rewetting stress. Data averaged over ten sampling sites, bars indicate standard errors. Asterisks denote bacterial phyla with different relative abundance prior to and after the stress $(\mathrm{p}<0.05$, paired samples t-test $)$

contained higher proportions of Gammaproteobacteria and Planctomycetes and a lower proportion of Actinobacteria. Analogous results have been reported by Dimitriu and Grayston (2010) who found similar bacterial composition in organic and mineral layers in boreal soils. The lack of distinct soil horizon effect on the structure of soil bacterial community may be attributed to the confounding effect of topography (affecting the patterns of nutrient and moisture contents in organic and mineral horizons) and downward flow of extracellular DNA (Dimitriu and Grayston 2010).

The effect of drought and rewetting stress on diversity and structure of bacterial communities

Drought and rewetting stress caused a small or moderate decrease of microbial biomass in the studied soils. Drought 
Fig. 2 The canonical correspondence analysis (CCA) loading plot of the bacterial structure composition in relation to soil properties and the drought and rewetting stress in the $\mathrm{O}$ horizon (a) and mineral soil (c) and the ordination plots of the relationships between bacterial phyla and soil properties in the $\mathrm{O}$ horizon (b) and mineral soil (d) for forest soils sampled in two regions (OLK - Olkusz region, LEG - Legnica region). Soil properties include toxicity index (TI), soil $\mathrm{pH}$ in $\mathrm{KCl}(\mathrm{pH})$, contents of organic $\mathrm{C}\left(\mathrm{C}_{\mathrm{org}}\right)$, total $\mathrm{N}\left(\mathrm{N}_{\mathrm{t}}\right)$. Drought and rewetting stress included as "Stress" variable. In the ordination plots, empty diamonds denote the sites prior to and filled diamonds the sites after the stress

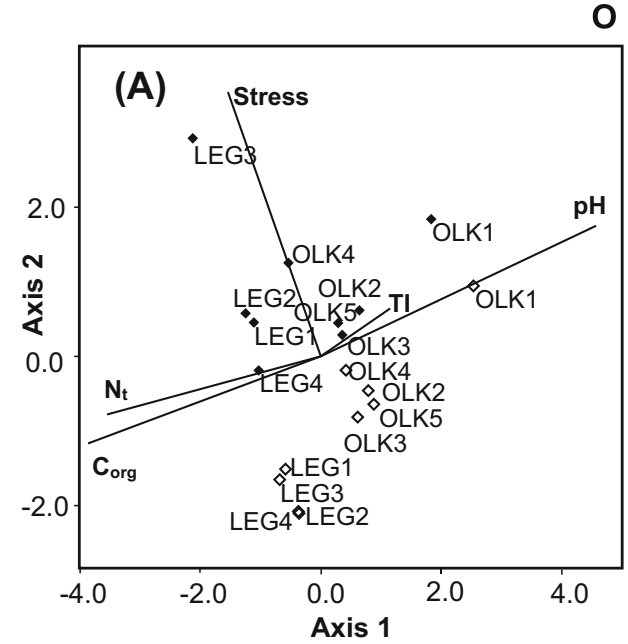

O horizon

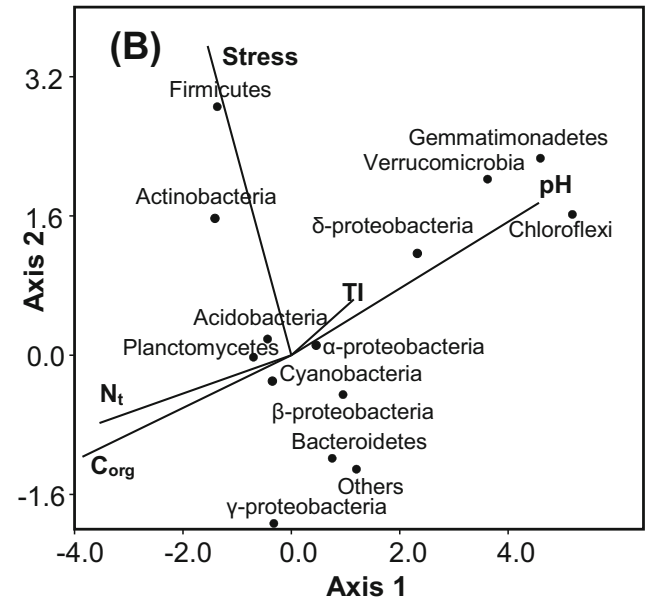

Mineral soil
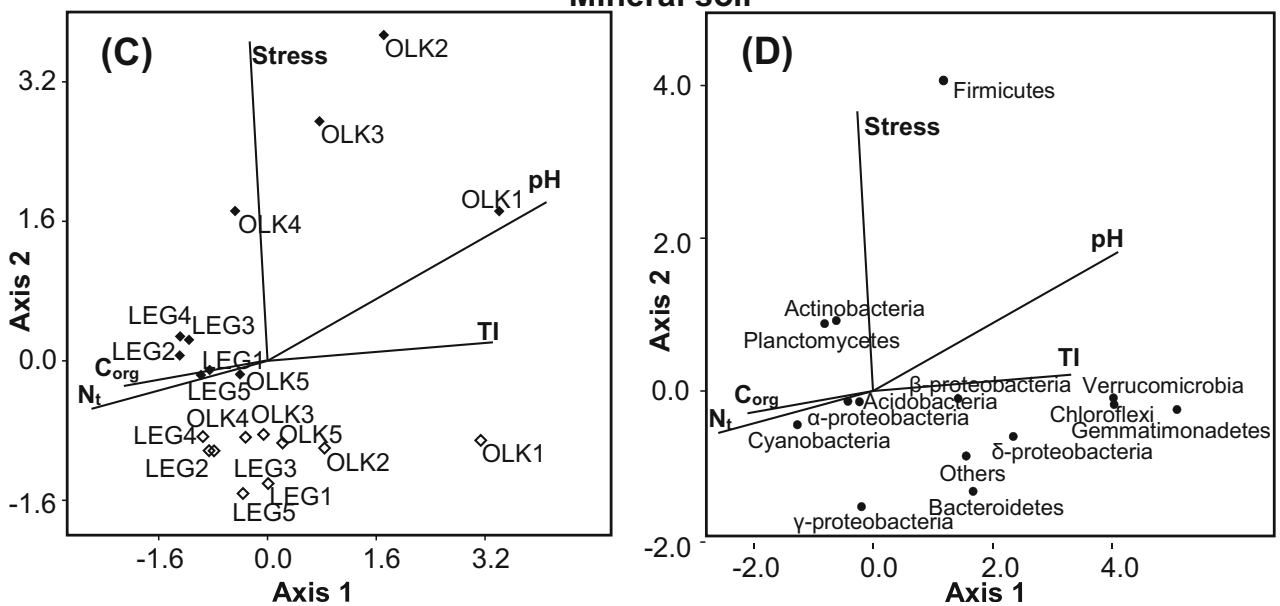

periods are known to cause microbial biomass decline in forest soils (Schimel et al. 1999). However, drought and rewetting is the most frequently occurring environmental stress, and the most common soil bacteria have developed several survival mechanisms (Schimel et al. 2007; Barnard et al. 2013). This may explain the small decrease of microbial biomass in our studied soils. The decline of microbial biomass was accompanied by a small loss of bacterial diversity indicating that despite various survival mechanisms available to soil bacteria, some of them are vulnerable to this kind of stress and may become entirely extinct after prolonged drought.

Different bacterial phyla were differently affected by the drought and rewetting stress resulting in considerable change in the structure of soil bacterial communities. The obtained results confirmed that Gram-positive bacteria are more resistant to drought and rewetting stress than the Gram-negative bacteria (Schimel et al. 2007). Increased shares after the stress, were found for Actinobacteria and Firmicutes. Actinobacteria and Firmicutes are Gram-positive bacteria and many of them are known to form spores, which are resistant to desiccation and can survive under drought conditions (Singh et al. 2007; Zhang and Xu 2008). These two bacterial phyla could not be classified either as oligo- or copiotrophs by Fierer et al. (2007). However, Barnard et al. (2013) reported that desiccation stimulated ribosomal synthesis of Actinobacteria, and this may explain their higher relative abundance after the drought and rewetting stress in our study.

The increased shares after drought and rewetting stress were found also for Acidobacteria. However, this effect was evident only in the $\mathrm{O}$ horizon. In the A horizon, the reaction of Acidobacteria to the stress was variable and highly dependent on soil $\mathrm{pH}$. In more acid soils $(\mathrm{pH}<\sim 5)$ the relative abundance of Acidobacteria increased after the stress, whereas in the less acid ones it decreased. Acidobacteria are oligotrophs well adapted to acid soils and probably that is why at lower $\mathrm{pH}$ they were better able to survive the drought and rewetting stress compared to other bacterial phyla (Ward et al. 2009). At higher $\mathrm{pH}$ values, however, other phyla - in particular, Firmicutes and Betaproteobacteria - proved more resistant and increased their relative abundance after the drought and rewetting stress.

Gram-negative bacteria generally decreased in relative abundance after drought and rewetting stress. The only Gram-negative phylum that appeared resistant to drought 
and rewetting stress was Planctomycetes, which increased in relative abundance after the stress in the A horizon. Planctomycetes are slow growing, aerobic bacteria that have several unusual characteristics: they lack peptidoglycan in their cell walls, their cells are divided by inner membranes into several compartments, and their genomes tend to be large (Buckley et al. 2006). Our result suggests that they are more resistant to drought and rewetting stress than other Gramnegative bacteria.

The relative abundance of Proteobacteria and Bacteroidetes decreased after drought and rewetting stress. These two phyla represent Gram-negative bacteria characterized by high sensitivity to environmental disturbances and vulnerability to drought stress (Uhlirova et al. 2005; Schimel et al. 2007; Barnard et al. 2013). They are mostly considered r-strategists decreasing in numbers under unfavorable conditions and boosting when the conditions improve (Lu et al. 2006; Singh et al. 2007). Among Proteobacteria, the class of Gammaproteobacteria was most severely affected by drought and rewetting stress. Gammaproteobacteria play a major role in important biogeochemical processes being involved in decomposition of numerous $\mathrm{C}$ compounds including phenols, PAHs, alkaloids, and carbohydrates (Abd-El-Haleem et al. 2002; Padmanabhan et al. 2003; Cleveland et al. 2007). Cleveland et al. (2007) suggested that Gammaproteobacteria may be disproportionally important to the decomposition of labile C compounds in soils. High vulnerability of Gammaproteobacteria to drought and rewetting stress implies that prolonged drought periods followed by rapid rewetting may have a strong impact on $\mathrm{C}$ cycling in temperate forest soils.

In both studied soil horizons, the drought and rewetting stress decreased significantly the relative proportion of less abundant bacterial taxa referred to as others. Distinct decline of these rare bacterial species indicates their vulnerability to drought and rewetting stress. The importance of rare bacterial taxa for soil functioning is unknown (Gans et al. 2005; Hol et al. 2010). However, rare species can play essential roles in soil functioning when they perform specific functions. The importance of rare bacterial species has been highlighted by Hol et al. (2010), who reported that rare soil bacteria were involved in complex community relationships affecting plant productivity and interactions between plants and herbivores.

The method applied to study structure of soil bacterial communities was based on the analysis of bacterial DNA extracted from the soil; therefore, the obtained results may be biased by the presence of DNA from dead microorganisms (Wackernagel 2006). However, microbial DNA is relatively rapidly decomposed when released to soil, in particular at early stages of its decomposition (Wackernagel 2006). DNA may be protected in soils owing to binding to clay minerals (Nielsen et al. 2006). However, our soils contained only small amounts of clay particles. Therefore, we presume that the contribution of DNA from dead bacteria in our study was negligible, and the observed changes result from the stressinduced alteration of soil bacterial communities.

The effect of soil properties on the reaction of particular bacterial phyla to drought and rewetting stress

The effect of drought and rewetting on soil microbial properties has been extensively studied (Schimel et al. 1999; Uhlirova et al. 2005; Hueso et al. 2012; Barnard et al. 2013). However, the role of soil chemical properties as factors that may modify the reaction of soil bacteria to this kind of stress received less attention. The CCA analysis applied in our study revealed that the reaction of several bacterial phyla to drought and rewetting stress depended on chemical soil properties. In particular, strong effect on the reaction of several bacterial groups to the applied stress was from soil $\mathrm{pH}$. The effect of soil acidity was evident in both studied soil horizons. Soil $\mathrm{pH}$ has been described as a powerful control of soil microorganisms (Lauber et al. 2009; Rousk et al. 2010; Tripahti et al. 2012) affecting diversity and structure of soil microbial communities either directly (Rousk et al. 2010) or indirectly through changes in carbon and nutrient availability (Kemmitt et al. 2006). Our results suggest that the effect of soil $\mathrm{pH}$ on the structure of soil bacterial communities may be through altering the reaction of particular bacterial groups to commonly occurring environmental stressors.

Strong influence of soil $\mathrm{pH}$ on the reaction of some bacterial groups to drought and rewetting stress suggests that the effect of prolonged drought periods on microbial processes may differ depending on soil acidity. For instance, in the $\mathrm{O}$ horizon we found that the decline of Gammaproteobacteria, Bacteroidetes, and rare bacterial taxons ("others") was larger at lower $\mathrm{pH}$ values. In consequence, stronger negative effects on the soil process driven by these bacteria should be expected in more acid soils compared with the less acid and neutral ones. In particular, decomposition of labile $\mathrm{C}$ compounds may be seriously affected in more acid soils due to the decrease of Gammaproteobacteria that are highly important for this process (Padmanabhan et al. 2003).

Differences in soil $\mathrm{pH}$ may lead to different reactions to drought and rewetting stress of the same bacterial groups. For instance, in the A horizon we have observed that in more acid soils the share of Betaproteobacteria decreased after the stress decreased, whereas in less acid ones it increased. For Alphaproteobacteria and Acidobacteria, the opposite was the case. Such a variable reaction of some bacterial groups may impede their ecological classification, and therefore, soil $\mathrm{pH}$ should always be considered when assessing the effects of stressing factors on different groups of soil bacteria.

The reaction of soil bacteria to drought and rewetting stress was related not only to soil $\mathrm{pH}$, but also to the contents of $\mathrm{C}_{\text {org }}$ and $\mathrm{N}_{\mathrm{t}}$. This suggests that the reaction to the drought and 
rewetting stress may depend on the content of nutrients $\left(\mathrm{N}_{\mathrm{t}}\right)$ and energy source $\left(\mathrm{C}_{\mathrm{org}}\right)$ in soil. However, the $\mathrm{C}_{\text {org }}$ and $\mathrm{N}_{\mathrm{t}}$ contents were inversely related to soil $\mathrm{pH}$. Therefore, we cannot rule out that the effect of $\mathrm{C}_{\text {org }}$ and $\mathrm{N}_{\mathrm{t}}$ contents was at least partly due to their negative correlation with soil $\mathrm{pH}$. It is known that low $\mathrm{pH}$ may result in retarded organic matter decomposition in soils (Kemmitt et al. 2006). In such a case, the influence of $\mathrm{C}_{\text {org }}$ and $\mathrm{N}_{\mathrm{t}}$ contents for the reaction of soil bacteria to drought and rewetting stress would be another expression of the $\mathrm{pH}$ effect.

The heavy metal pollution also affected the reaction of soil bacteria to drought and rewetting stress. However, despite large concentrations of heavy metals in some of the studied soils, their effect was weaker compared to other soil properties. This demonstrates that even in areas highly polluted with heavy metals, natural soil properties such as $\mathrm{pH}$ or nutrient contents may be more important than the pollution in determining some properties of microbial communities. In line with our results, Azarbad et al. (2014) reported a minor effect of heavy metal pollution on several functional gene families related to i.a. stress responses in microbial communities from soils polluted with high levels of $\mathrm{Pb}, \mathrm{Zn}$, and $\mathrm{Cd}$.

\section{Conclusions}

Long periods of drought followed by rapid rewetting decreased microbial biomass, diversity of soil bacterial communities, and brought about changes in bacterial community structure. Different bacterial phyla differed in their vulnerability to this kind of stress. In general, Gram-positive bacterial phyla Actinobacteria and Firmicutes - were more resistant to drought and rewetting stress than the Gram-negative bacteria. The copiotrophic, Gram-negative bacteria such as Proteobacteria and Bacteroidetes were more vulnerable and usually decreased in share after the drought and rewetting. However, their reaction depended on the soil properties in particular on soil $\mathrm{pH}$. Low soil $\mathrm{pH}$ reduced the ability of copiotrophic Gammaproteobacteria and Bacteroidetes as well as the rare bacterial species to withstand drought and rewetting stress. Since these bacteria (in particular Gammaproteobacteria) are responsible for important soil processes the drought and rewetting stress may have stronger effect on the functioning of more acid soils compared with the less acid and the neutral ones.

The reaction of several other groups of bacteria to drought and rewetting stress depended also on various soil properties such as the contents of $\mathrm{N}$ and organic $\mathrm{C}$ and the heavy metal pollution. Therefore, chemical properties of soils should always be regarded when assessing the effect of drought and rewetting on soil bacterial communities.
Acknowledgments The study was financed by Norwegian Financial Mechanism and EEA Financial Mechanism, project FRISC (Factors of Population Extinction Risk, no: GOL PL 0419) and Jagiellonian University funds (project no. DS 759).

Open Access This article is distributed under the terms of the Creative Commons Attribution License which permits any use, distribution, and reproduction in any medium, provided the original author(s) and the source are credited.

\section{References}

Abd-El-Haleem D, Moawad H, Zaki EA, Zaki S (2002) Molecular characterization of phenol-degrading bacteria isolated from different Egyptian ecosystems. Microb Ecol 43:217-224

Allison SD, Martiny JBH (2008) Resistance, resilience and redundancy in microbial communities. Proc Natl Acad Sci U S A 105(1): $11512-11519$

Anderson JPE, Domsch KH (1978) A physiological method for the quantitative measurement of microbial biomass in soils. Soil Biol Biochem 10:215-221

Azarbad H, Niklińska M, Laskowski R, van Straalen NM, van Gestel CAM, Zhou J, He Z, Wen C, Röling WFM (2014) Microbial community composition and functions are resilient to metal pollution along two forest soil gradients. FEMS Microbiology Ecology. In press

Barnard RL, Osborne CA, Firestone MK (2013) Responses of soil bacterial and fungal communities to extreme desiccation and rewetting. The ISME Journal, 1 - 13, doi:10.1038/ ismej2013104

Bauhus J, Khanna PK (1999) The significance of microbial biomass in forest soils. In: Rastin N, Bauhus J (eds) Going Underground Ecological Studies in Forest Soils. Research Signpost, Trivandrum, pp 77-110

Blanca J, Chevreux B (2010) bioinf.comav.upv.es/sff_crumbs/

Buckley DH, Huangyutitham V, Nelson TA, Rumberger A, Thies JE (2006) Diversity of Planctomycetes in soil in relation to soil history and environmental heterogeneity. Appl Environ Microbiol 72: $4522-4531$

Chodak M (2002) Chemical and biological characteristics of organic layers under spruce and beech stands. Berichte des Forschungszentrums Waldökosysteme, Reihe A, Bd180

Chodak M, Gołębiewski M, Morawska-Płoskonka J, Kuduk K, Niklińska M (2013) Diversity of microorganisms from forest soils differently polluted with heavy metals. Appl Soil Ecol 64:7-14

Cleveland CC, Nemergut DR, Schmidt SK, Townsend AR (2007) Increases in soil respiration following labile carbon additions linked to rapid shifts in soil microbial community composition. Biogeochemistry 82:229-240

Dimitriu PA, Grayston SJ (2010) Relationship between soil properties and patterns of bacterial $\beta$-diversity across reclaimed and natural boreal forest soils. Microb Ecol 59:563-573

Edgar RC, Haas BJ, Clemente JC, Quince C, Knight R (2011) UCHIME improves sensitivity and speed of chimera detection. Bioinformatics 27:2194-2200

Evans SE, Burke IC (2012) Carbon and nitrogen decoupling under an 11year drought in the shortgrass steppe. Ecosystems 16:20-33

Fierer N, Bradford MA, Jackson RB (2007) Toward an ecological classification of soil bacteria. Ecology 88:1354-1364 
Gans J, Wolinsky M, Dunbar J (2005) Computational improvements reveal great bacterial diversity and high metal toxicity in soil. Science 309:1387-1390

Göranson H, Godbold DL, Jones DL, Rousk J (2013) Bacterial growth and respiration responses upon rewetting dry forest soils: Impact of drought legacy. Soil Biol Biochem 57: 477-486

Hamady M, Walker J, Harris JK, Gold NJ, Knight R (2008) Errorcorrecting barcoded primers for pyrosequencing houndreds of samples in multiplex. Nat Methods 5:235-237

Hammer Ø, Harper DAT, Ryan PD (2001) PAST: Paleontological Statistics Software Package for Education and Data Analysis. Palaeontologia Electronica 4: 9 pp

Hol WHG, de Boer W, Termorshuizen AJ, Meyer KM, Schneider JH, van Dam NM, van Veen JA, van der Putten WH (2010) Reduction of rare soil microbes modifies plant-herbivore interactions. Ecol Lett 13:292-301

Hueso SC, García C, Hernández T (2012) Severe drought conditions modify the microbial community structure, size and activity in amended and unamended soils. Soil Biol Biochem 50:167-173, 167

Hurlbert SH (1984) Pseudoreplication and the design of ecological field experiments. Ecol Monographs 54:187-211

Huse SM, Huber JA, Morrison HG, Sogin ML, Welch DM (2007) Accuracy and quality of massively parallel DNA pyrosequencing. Genome Biol 8:R143

IPCC et al (2007) Climate change 2007: the physical science basis. In: Solomon S, Qin D, Manning M (eds) Contribution of working group I to the fourth assessment report of the intergovernmental panel on climate change. Cambridge University Press, Cambridge

Janssen PH (2006) Identifying the dominant soil bacterial taxa in libraries of 16S rRNA and 16S rRNA genes. Appl Environ Microbiol 72: $1719-1728$

Kemmitt SJ, Wright D, Goulding KWT, Jones DL (2006) pH regulation of carbon and nitrogen dynamics in two agricultural soils. Soil Biol Biochem 38:898-911

Kuramae EE, Yergeau E, Wong LC, Pijl AS, van Veen JA, Kowalchuk GA (2012) Soil characteristics more strongly influence soil bacterial communities than land-use type. FEMS Microbiol Ecol 79:12-24

Lauber CL, Hamady M, Knight R, Fierer N (2009) Pyrosequencingbased assessment of soil $\mathrm{pH}$ as a predictor of soil bacterial community structure at the continental scale. Appl Environ Microbiol 75: $5111-5120$

Liu Z, Lozupone C, Hamady M, Bushman FD, Knight R (2007) Short pyrosequencing reads suffice for accurate microbial community analysis. Nucleic Acids Res 35:e120

Lu Y, Rosencrantz D, Liesack W, Conrad R (2006) Structure and activity of bacterial community inhabiting rice roots and the rhizosphere. Environ Microbiol 8:1351-1360

Maracchi G, Sirotenko O, Bindi M (2005) Impacts of present and future climate variability on agriculture and forestry in the temperate regions: Europe. Clim Change 70:117-135

Nacke H, Thürmer A, Wollherr A, Will C, Hodac L, Herold N, Schöning I, Schrumpf M, Daniel R (2011) Pyrosequencing-based assessment of bacterial community structure along different management types in German forest and grassland soils. PLoS ONE 6(2): e17000 doi: 10.1371/journalpone0017000

Nannipieri P, Ascher J, Ceccherini MT, Landi L, Pietramellara G, Renella G (2003) Microbial diversity and soil functions. Eur J Soil Sci 54: 655-670

Nielsen MN, Winding A (2002) Microorganisms as indicators of soil health. NERI Tech Rep 388:27-30

Nielsen KM, Calamai L, Pietramellara G (2006) Stabilization of Extracellular DNA and Proteins by Transient Binding to Various Soil Components. In: Nucleic Acids and Proteins in Soil, Nannipieri P and Smalla C (Eds), Soil Biology Vol 8, Springer, pp $141-158$
Niklińska M, Chodak M, Laskowski R (2005) Characterization of the forest humus microbial community in a heavy metal polluted area. Soil Biol Biochem 37:2185-2194

Niklińska M, Chodak M, Laskowski R (2006) Pollution-induced community tolerance of microorganisms from forest soil organic layers polluted with $\mathrm{Zn}$ or $\mathrm{Cu}$. Appl Soil Ecol 32:265-272

Padmanabhan P, Padmanabhan S, DeRito C, Gray A, Gannon D, Snape JR, Tsai CS, Park W, Jeon C, Madsen EL (2003) Respiration of ${ }^{13} \mathrm{C}$ labelled substrates added to soil in the field and subsequent $16 \mathrm{~S}$ rRNA gene analysis of ${ }^{13} \mathrm{C}$-labelled soil DNA. Appl Environ Microbiol 69:1614-1622

Pesaro M, Nicollier G, Zeyer J, Widmer F (2004) Impact of soil dryingrewetting stress on microbial communities and activities and on degradation of two crop protection products. Appl Environ Microbial 70:2577-2587

Preem J-K, Truua J, Truu M, Mandera Ü, Oopkaupa K, Lohmus K, Helmisaari H-S, Uri V, Zobel M (2012) Bacterial community structure and its relationship to soil physico-chemical characteristics in alder stands with different management histories. Ecol Eng 49:10-17

Quince C, Lanzen A, Davenport RJ, Turnbaugh PJ (2001) Removing noise from pyrosequenced amplicons. BMC Bioinformatics 2011, 12:38 doi:10.1186/1471-2105-12-38

Raubuch M, Beese F (1995) Pattern of microbial indicators in forest soils along an European transect. Biol Fertil Soils 19:362-368

Rousk J, Bååth E, Brookes PC, Lauber CL, Lozupone C, Caporaso JG, Knight R, Fierer N (2010) Soil bacterial and fungal communities across a $\mathrm{pH}$ gradient in an arable soil. ISME J 4:1340-1351

Schimel JP, Gulledge JM, Clein-Curley JS, Lindstrom JE, Braddock JF (1999) Moisture effects on microbial activity and community structure in decomposing birch litter in the Alaskan taiga. Soil Biol Biochem 31:831-838

Schimel J, Balser TC, Wallenstein M (2007) Microbial stress-response physiology and its implications for ecosystem function. Ecology 88: 21386-21394

Schlichting E (1966) Blume HO. Bodenkundliches Praktikum Paul Parey, Hamburg

Schloss PD, Westcott SL, Ryabin T, Hall JR, Hartmann M, Hollister EB, Lesniewski RA, Oakley BB, Parks DH, Robinson CJ, Sahl JW, Stres B, Thallinger GG, Van Horn DJ, Weber CF (2009) Introducing Mothur: open-source, platform-independent, community-supported software for describing and comparing microbial communities. Appl Environ Microbiol 75:7537-7541

Sheldrick BH, Wang C (1993) Particle size distribution. In: Carter MR (ed) Soil sampling and methods of analysis. Lewis Publishers, Boca Raton

Singh BK, Munro S, Potts JM, Millard P (2007) Influence of grass species and soil type on rhizosphere microbial community structure in grassland soils. Appl Soil Ecol 36:147-155

Tripahti BM, Kim M, Singh D, Lee-Cruz L, Lai-Hoe A, Ainuddin AN, Go R, Rahim RA, Husni MH, Chun J, Adams JM (2012) Tropical soil bacterial communities in Malaysia: $\mathrm{pH}$ dominates in the equatorial tropics too. Microb Ecol 64:474-484

Uhlirova E, Elhottova D, Třiska J, Šantrůčková H (2005) Physiology and microbial community structure in soil at extreme water content. Folia Microbiol 50:161-166

Wackernagel W (2006) The Various Sources and the Fate of Nucleic Acids in Soil. In: Nucleic Acids and Proteins in Soil, Nannipieri P and Smalla C (eds), Soil Biology Vol 8, Springer, pp 117 - 140

Ward NL, Challacombe JF, Janssen PH, Henrissat B, Coutinho PM, Wu M, Xie G, Haft DH, Sait M, Badger J, Barabote RD, Bradley B, Brettin TS, Brinkac LM, Bruce D, Creasy T, Daugherty SC, Davidsen TM, DeBoy RT, Detter JC, Dodson RJ, Durkin AS, Ganapathy A, Gwinn-Giglio M, Han CS, Khouri H, Kiss H, Kothari SP, Madupu R, Nelson KE, Nelson WC, Paulsen I, Penn K, Ren Q, Rosovitz MJ, Selengut JD, Shrivastava S, Sullivan SA, Tapia R, Thompson LS, Watkins KL, Yang Q, Yu C, Zafar N, Zhou L, Kuske CR (2009) Three genomes from the phylum Acidobacteria 
provide insight into the lifestyles of these microorganisms in soils. Appl Environ Microbiol 75:2046-2056

Welp G (1999) Inhibitory effects of the total and water-soluble concentrations of nine different metals on the dehydrogenase activity of a loess soil. Biol Fertil Soils 30:132-139
Yeates C, Gillings MR, Davison AD, Altavilla N, Veal DA (1997) PCR amplification of crude microbial DNA extracted from soil. Letters Appl Microbiol 25:303-307

Zhang L, Xu Z (2008) Assessing bacterial diversity in soil. J Soils Sediments 8:379-388 